\title{
Morphological survey as powerful detection tool of pure and local phenotypes in Salmo trutta complex
}

\author{
Massimo Lorenzoni ${ }^{1}$, Antonella Carosi ${ }^{1,{ }^{*}}$, Massimo Giovannotti ${ }^{2}$, Gianandrea La Porta ${ }^{1}$, \\ Andrea Splendiani ${ }^{2}$ and Vincenzo Caputo Barucchi ${ }^{2}$ \\ ${ }^{1}$ Department of Chemistry, Biology and Biotechnologies, University of Perugia, via Elce di Sotto, Perugia, Italy \\ ${ }^{2}$ DiSVA, Università Politecnica delle Marche, via delle Brecce Bianche, Ancona, Italy
}

Received: 7 June 2019 / Accepted: 13 October 2019

\begin{abstract}
The native Mediterranean trout populations in central Italy are at risk of extinction. Hybridization with the alien Atlantic trout represents one of the major threats to the species. The main aim of the research was to test the efficiency of morphological characterization in revealing alien trout introduction, pure lineages and local adaptations, in five watersheds of central Apennines (Italy). Data analysis was carried out for a total of 258 specimens already genetically identified. The results of the multivariate analysis, performed using 10 qualitative and 47 quantitative variables, revealed two distinct phenotypic groups and confirmed, at a morphological level, the genetic separation between Atlantic and Mediterranean trout. The morphological variables that play a key role in the discrimination of the Mediterranean trout were: (i) number of parr marks with striped pattern, (ii) adipose fin mainly with white color and without black spots, and (iii) number of black opercular spots, compared to the Atlantic trout. The geometric analysis revealed the importance of the spatial arrangements of spots on the fish flank and the shape of caudal peduncle in discriminating different Mediterranean populations. The information collected confirmed the powerful of morphological surveys in the screening of conservation status of wild trout populations.
\end{abstract}

Keywords: Mediterranean basins / native trout / morphometric characteristics / geometric analysis / biodiversity conservation

\begin{abstract}
Résumé - L'étude morphologique comme outil puissant d'identification des phénotypes purs et locaux dans le complexe Salmo trutta. Les populations indigènes de truites méditerranéennes du centre de l'Italie sont menacées d'extinction. L'hybridation avec la truite atlantique exotique représente l'une des principales menaces pour l'espèce. L'objectif principal de la recherche était de tester l'efficacité de la caractérisation morphologique pour révéler l'introduction de truites exotiques, les lignées pures et les adaptations locales, dans cinq bassins versants des Apennins centraux (Italie). L'analyse des données a été effectuée pour un total de 258 spécimens déjà identifiés génétiquement. Les résultats de l'analyse multivariée, réalisée à partir de 10 variables qualitatives et 47 variables quantitatives, ont révélé deux groupes phénotypiques distincts et confirmé, au niveau morphologique, la séparation génétique entre la truite atlantique et la truite méditerranéenne. Les variables morphologiques qui jouent un rôle clé dans la discrimination de la truite méditerranéenne sont : i) le nombre de marques de parr à motif rayé, ii) la nageoire adipeuse principalement de couleur blanche et sans taches noires, et iii) le nombre de taches operculaires noires, comparé à la truite Atlantique. L'analyse géométrique a révélé l'importance de l'agencement spatial des taches sur le flanc du poisson et de la forme du pédoncule caudal pour distinguer les différentes populations méditerranéennes. Les informations recueillies ont confirmé la puissance des analyses morphologiques dans le diagnostic de l'état de conservation des populations de truites sauvages.
\end{abstract}

Mots clés : Bassins méditerranéens / truites indigenes / caractéristiques morphométriques / analyse géométrique / conservation de la biodiversité

\footnotetext{
*Corresponding author: acarosi@libero.it
} 


\section{Introduction}

The Mediterranean basin is characterized by very high biodiversity values and it was listed among the most important global Biodiversity Hotspot as regards freshwater fish species (Myers et al., 2000). In particular, Italy, because of the presence of a large number of endemic species, can be considered a crucial area for the fish biodiversity conservation (Smith and Darwall, 2006). At present, the Mediterranean trout Salmo cettii Rafinesque, 1810 is considered by some authors the native stream-resident brown trout of the Apennine and main islands of Italy (Sardinia, Corsica and Sicily) (Zaccara et al., 2015; Duchi, 2018), although probably the taxonomy of the Mediterranean trout has not yet been resolved. The Mediterranean trout is one of the freshwater fish species threatened in this area, being the residual native trout populations listed as Critically Endangered in the IUCN Red List of Italian vertebrates (Rondinini et al., 2013). It was also included in Annex II of the Habitat 92/43/CEE for which 'conservation requires the designation of special area of conservation' (Genovesi et al., 2014). The main threats for this species are represented by water pollution, water abstractions, interruptions of river continuity, overfishing and introduction of non-native trout (Largiadèr and Scholl, 1996; Berrebi et al., 2000; Aparicio et al., 2005; Dudgeon et al., 2006; Clavero et al., 2010; Araguas et al., 2017). Furthermore, because of global climate change, it is possible to predict in the Mediterranean rivers future scenarios with an increase of the water temperature, resulting in a reduction of the environments with thermal conditions suitable for the coldwater species as the brown trout (Ficke et al., 2007; Buisson et al., 2008; Almodovar et al., 2011; Filipe et al., 2013). Because of all these threats, it can be assumed a significant further decline of the wild populations in the future.

As reported for other Italian basins (Nonnis Marzano et al., 2003; Lorenzoni et al., 2004; Gratton et al., 2014; Zaccara et al., 2015; Splendiani et al., 2016), also in the central Apennine watercourses the genetic integrity of the Mediterranean trout is strongly threatened by the introgressive hybridization with the Atlantic brown trout Salmo trutta s. s. Linnaeus, 1758 (Giuffra et al., 1996; Poteaux et al., 1999; Nonnis Marzano et al., 2003; Splendiani et al., 2006, 2013; Gratton et al., 2013; Carosi et al., 2015; Lorenzoni et al., 2018, 2019), a non-native species introduced in the study area in the last century in favor of fishing activities (Splendiani et al., 2016). It is known that the introduction of an exotic species can cause the extinction of the native species by introgressive hybridization (Rhymer and Simberloff, 1996). This is particularly true for salmonid fishes, for the ease with which the species hybridize and for the massive introduction of allochthonous specimens carried out with stocking programs (Poteaux et al., 1999). Indeed, in Italian watercourses trout fishing is among the most favorite activities for sport anglers (Pedicillo et al., 2010). In the study area, the hybridization between Atlantic and Mediterranean trout resulted in the loss of locally adapted genotypes and in some cases, it led to the local extinction of the native populations (Splendiani et al., 2016). However, as reported for some Denmark rivers (Hansen, 2002), also in the Apennine area previous studies showed a surprising resilience of native brown trout genetic diversity despite the massive stocking activities occurred in the last decades (Caputo et al., 2004); a selection against stocked domesticated trout is probably related to the hydrogeological features of central Apennine rivers (Splendiani et al., 2013). This aspect has contributed (together with geographical isolation and poor stream accessibility), to the preservation of the genetic integrity of some native Mediterranean trout populations (Lorenzoni et al., 2019; Splendiani et al., 2019).

Despite the high conservational and economic interest of the Mediterranean trout (Suarez et al., 2001), many aspects of its biology are still poorly known, and information on morphological characteristics that allow the distinction of pure populations (Zaccara et al., 2015) from the Atlantic species and hybrids is incomplete (Querci et al., 2013).

Thus, the main aim of the research was to test the efficiency of morphological characterization in revealing alien trout introduction, pure lineages and local adaptations, through the previous attribution based on genetic data. The combination of genetic and morphological characterization offers the opportunity to identify valid phenotypic traits that allow the recognition of alien specimens in the field; this allows to better focus the application of genetic tools to not-attributable morphological phenotype (i.e. hybrid specimens). With this purpose the morphological differences between $S$. cettii and $S$. trutta in the central Apennines (Italy), and the morphometric variability inside the Mediterranean populations already genetically determined in a rigorous way, were investigated. This approach was based on: (i) measurement and counting of traditional morphometric characters, (ii) color pattern characterization, describing number and arrangement of the spots on various part of the fish body (flanks, head and fins), and (iii) analyses of the body shape through the identification of landmarks on the fish profile, that showed anatomical significance, according to the method proposed by Strauss and Bookstein (1982). Previous studies have shown the effectiveness of landmark-based geometric morphometrics, as a powerful technique for the study of body size and shape variation, and identification of its causes (Adams et al., 2013). Indeed, while traditional morphometric measures consider irregular and redundant aspects of the body shape, the geometrical analysis is particularly sensitive to the body shape changes of the specimens, so the distances between landmarks may play a crucial role in the discrimination among fish stocks (Lorenzoni et al., 2004). In particular, geometric morphometrics, frequently used in ichthyology (Cadrin, 2000), provides an effective tool for studying the variability among congeneric species that hybridize (Hayden et al., 2010), as $S$. cettii and S. trutta, and within fish populations. Moreover, one of the major advantages of the application of morphometric methods is that the data can be collected quickly in a large number of specimens, without requiring their sacrifice which is absolutely to be avoided especially in the case of a species at risk of extinction (Lorenzoni et al., 2004).

\section{Material and methods}

\subsection{Study area}

The study area encompasses four watersheds, namely Cesano, Potenza, Chienti and Tenna belonging to the Adriatic 


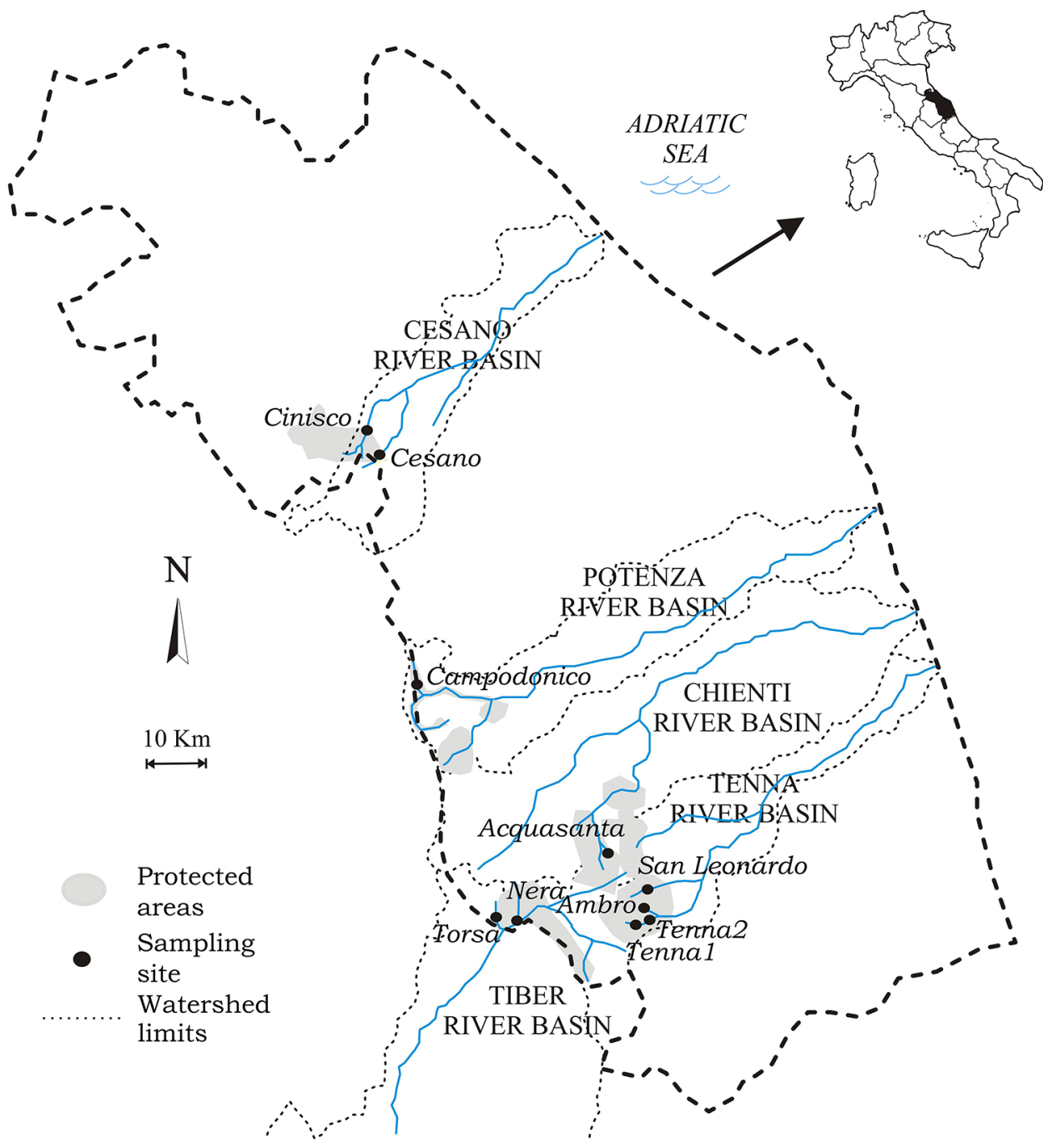

Fig. 1. Study area and location of the sampling sites.

slope of Italy, and one belonging to the Tirrenic side (Nera River within the Tiber river basin) (Fig. 1). Except for the Campodonico creek (Potenza river basin), which flows in a marl calcareous valley, the remaining basins are characterized by a mountain calcareous system. In all cases, the main type of land use is represented by wooded areas. All sites were located in the upper stream reaches, at a short distance from the springs. The watercourses considered are of modest dimensions in terms of average width and depth, and have similar environmental characteristics in terms of hydrogeology and flow rates; the only exception is represented by the Nera River, which in the investigated stretches is slightly larger than the others (Tab. 1). Their torrential features, with marked flow rate oscillations and a high susceptibility to drought periods in summer, are made worse by the intensive exploitation for human use.

\subsection{Data collection}

Data were collected from October 2010 to June 2016 in 10 sampling sites (Fig. 1). A total of 258 specimens belonging to 9 different watercourses were analyzed (Tab. 1). Fishes were collected by electrofishing, anaesthetized, measured in weight and length, placed on a copy stand and photographed from the left side using a Nikon D300 camera positioned by means of a tripod on a millimeter table. For each specimen, an adipose fin clip was removed and conserved in $99 \%$ ethanol until DNA extraction for further genetic analysis, and a sample of scales was collected for age determination. The age was attributed in the laboratory by integrating the scalimetric and the Petersen methods (Bagenal, 1978).

\subsection{Genetic analysis}

Genetic analyses were performed by using nuclear markers (locus LDH-C1* and 11 microsatellites) (see Splendiani et al., 2019). Bayesian clustering implemented in STRUCTURE 2.3.2.1 was used for estimating the number of groups $(k)$ represented by all sampled individuals (Pritchard et al., 2000; Falush et al., 2003). For more details, see Splendiani et al. (2019). 
M. Lorenzoni et al.: Knowl. Manag. Aquat. Ecosyst. 2019, 420, 48

Table 1. Morphologic characteristics of the sampling sites, and number of specimens belonging to the different genetic groups according to the $q$ values: native Mediterranean $(q \geq 0.998)$, hybrid/introgressed $(0.002<q<0.998)$, alien Atlantic $(q \leq 0.002)$.

\begin{tabular}{|c|c|c|c|c|c|c|c|c|c|c|}
\hline Sampling site & Basin & $\begin{array}{l}\text { Watershed } \\
\text { area } \\
\left(\mathrm{km}^{2}\right)\end{array}$ & $\begin{array}{l}\text { Distance from } \\
\text { the source } \\
(\mathrm{km})\end{array}$ & $\begin{array}{l}\text { Average } \\
\text { slope } \\
(\%)\end{array}$ & $\begin{array}{l}\text { Altitude } \\
\text { (m a.s.1.) }\end{array}$ & $\begin{array}{l}\text { Average } \\
\text { width } \\
(\mathrm{m})\end{array}$ & $\begin{array}{l}\text { Average } \\
\text { depth } \\
(\mathrm{cm})\end{array}$ & $\begin{array}{l}\text { Mediterranean } \\
\text { group } \\
\left(n^{\circ} \text { specimen }\right)\end{array}$ & $\begin{array}{l}\text { Hybrid group } \\
\left(\mathrm{n}^{\circ} \text { specimen }\right)\end{array}$ & $\begin{array}{l}\text { Atlantic group } \\
\left(n^{\circ} \text { specimen }\right)\end{array}$ \\
\hline Acquasanta & Chienti & 7.09 & 2.65 & 17.02 & 800 & 4.7 & 15.8 & - & 12 & - \\
\hline Ambro & Tenna & 18.23 & 5.18 & 11.04 & 684 & 3.5 & 25.2 & 27 & 16 & - \\
\hline Campodonico & Potenza & 32.04 & 8.53 & 8.53 & 491 & 3.7 & 16.0 & - & 15 & - \\
\hline Cesano & Cesano & 12.06 & 5.37 & 5.37 & 471 & 3.8 & 17.9 & - & 1 & 63 \\
\hline Cinisco & Cesano & 9.04 & 5.42 & 5.42 & 447 & 3.1 & 13.4 & - & - & 10 \\
\hline Nera & Tiber & 164.94 & 33.04 & 4.27 & 495 & 7.0 & 26.0 & 3 & 16 & - \\
\hline San Leonardo & Tenna & - & 1.01 & 20.69 & 1008 & 2.5 & 20.0 & 39 & - & - \\
\hline Tenna 1 & Tenna & 21.78 & 2.27 & 2.27 & 920 & 3.0 & 13.8 & 2 & - & - \\
\hline Tenna 2 & Tenna & 22.60 & 2.99 & 2.99 & 830 & 4.4 & 15.0 & 3 & 12 & - \\
\hline Torsa & Tiber & 12.38 & 4.91 & 4.91 & 568 & 3.1 & 17.4 & 34 & 5 & - \\
\hline
\end{tabular}

STRUCTURE was also used to estimate the admixture coefficient $(q)$ of each individual and their $95 \%$ credible intervals (CI) in each wild sample. The individual values of $q$ ranged from 0 , that in the present study identifies a pure domestic trout, to 1 , that indicates a pure Mediterranean trout.

\subsection{Morphometric analysis}

Digital images were processed for the quantification of morphological variables, and calculation of the frequency of qualitative variables, using ImageJ software (Abramoff et al., 2004). According to Strauss and Bookstein (1982), a digital box truss network of 11 landmarks was created around each specimen in order to build an archive of comprehensive representation of fish form (Fig. 2). All measurements have been taken on the left side of the fish.

Morphological characterization was performed considering 10 qualitative and 47 quantitative characters, according to Aparicio et al. (2005), Kottelat and Freyhof (2007) and Zaccara et al. (2015) (Fig. 2). The black, red and brown spots were placed on the digital images, their coordinates $(x, y)$ were collected and subsequently processed in order to rebuild their spatial arrangement on the fish flank; with this aim, the average distance of the spots centroids has been calculated with respect to three reference points placed on the fish body: the fish centroid, the landmark 1, and the intersection between line passing through both landmarks 1-7 and the line passing through both perpendicular and landmark 3 (Fig. 2).

Based on the genetic characterization (see above), fish were divided into three different groups according to the $q$ values, namely native Mediterranean (Group1 $q \geq 0.998$ ), hybrid/introgressed (Group2 $0.002<q<0.998$ ) and alien Atlantic trout, (Group3 $q \leq 0.002$ ) (Tab. 1). Analysis of nominal scale data was carried out using correspondence analysis (CA), whereas a three-step analysis was elaborated for ratio scale data. In the first step, a normalization procedure was applied to remove allometric effects of body size (Lleonart et al., 2000); in the second step one-way ANOVA was used to compare the means of each quantitative variable retained by redundancy analysis; and in the third step statistically significant variables of ANOVA were entered in the stepwise discriminant analysis (DA) to reveal which variables discriminated between occurring groups. All statistical analyses were performed using the following software: $\mathrm{R}$ language and environment for statistical computing (R Core Team, 2016); Statistica 13 (Dell Inc., 2015). Values with $p<0.05$ were considered statistically significant.

\section{Results}

The total sample, composed of 258 specimens, was heterogeneous and representative of all sizes in the population. The total length ranged from 5.7 to $32.8 \mathrm{~cm}$ (mean $\pm \mathrm{SD}=$ $17.94 \pm 4.62$ ) and weight from 5.0 to $362.5 \mathrm{~g}$ (mean $\pm \mathrm{SD}=$ $72.3 \pm 57.0)$. Eight age classes $\left(0^{+}-7^{+}\right)$were identified.

25 quantitative variables showed statistically significant differences among groups at the one-way ANOVA (Tab. 2) and were retained by redundancy analysis.

Correspondence analysis produced a tight clustering of specimens into genetic groups and explained the most amount of variance along the first two axes. The $x$-axis (which explained $34.3 \%$ of the variance) was controlled by parr marks with striped pattern, adipose fin with white margin or black spots and the number of red spots aligned to the fish lateral line. The $y$-axis (23.6\% of total variance) was mainly driven by the number of operculum spots and the number of parr marks (Fig. 3).

The stepwise DA provided two significant discriminant functions (Wilks' lambda $=0.254, p<0.001$ ) which accounted for $79.0 \%$ and $21.0 \%$ of variability, respectively (Fig. 4). Variables that contribute most to the prediction of group membership are listed in Table 3. Along the axis described by DF1 the differences between Atlantic and Mediterranean trout emerged more clearly, although introgressed/hybrid individuals tend to overlap the Mediterranean trout with the highest probability of genetic integrity. According to this analysis and to the ANOVA results (Tab. 2), the Mediterranean trout was characterized by having a greater number of parr marks, by a color pattern characterized by a high intensity of black and red spots, a high number of opercular black spots, higher height of anal fin, and frequently by more than two ocular spots. Hybrid specimens were characterized by a less elongated snout, a 
a)

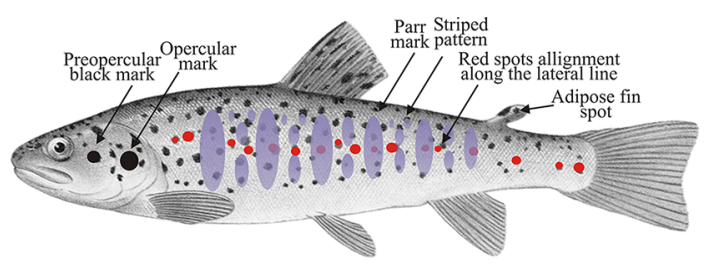

b)

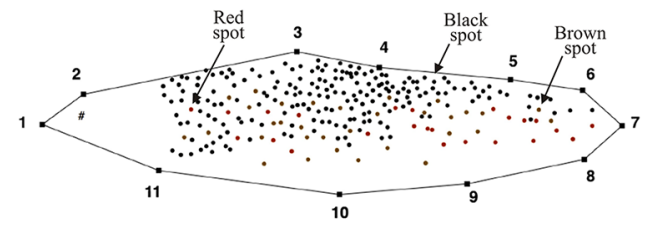

c)

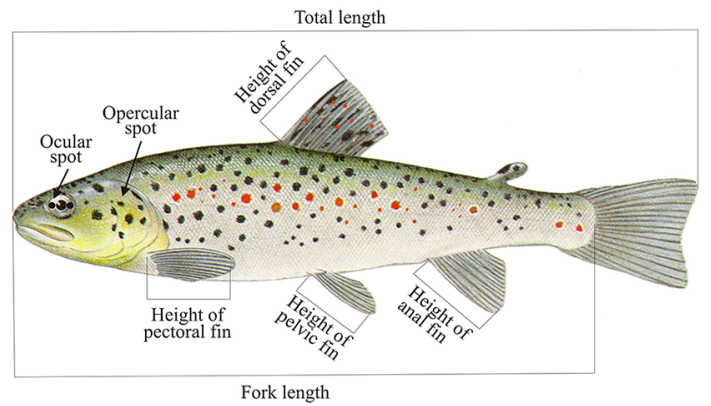

d)

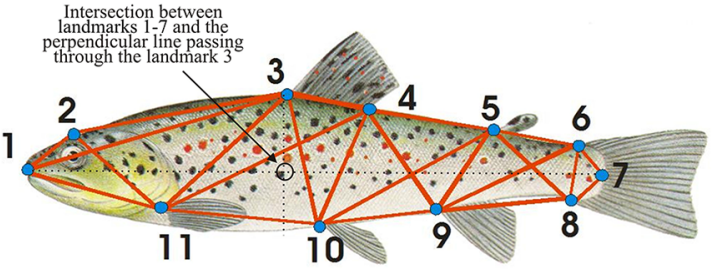

Fig. 2. (a) Qualitative variables: presence/absence of parr marks, striped pattern (defined as vertical dark stripes on the body sides of the fish), black mark in the pre-opercular region, black spot on the operculum, alignment of red spots mainly along the lateral line, adipose fin color (brown or white, with or without red, brown and black spots, with or without red margin); brown spots were given by the overlap between black and red spots. (b) Box-truss with localization of brown, red and black spots. (c) Quantitative nongeometric variables: total length, fork length, height of pectoral, anal and pelvic fins, number of red spots on the lateral line, number of ocular and opercular spots, number, frequency (i.e. abundance), intensity (i.e. the ratio between the number of spots and the fish surface) and proportion (i.e. the ratio between the number of spots of a certain color and the total number of spots) of brown, black and red spots on the flank, number, perimeter and area of parr marks. (d) Quantitative geometric variables. Two-dimensional landmarks positions and relative twenty-two distances: (1) anterior tip of the snout at upper jaw; (2) transition point between trunk and snout; (3) anterior insertion of the dorsal fin; (4) posterior insertion of the dorsal fin; (5) anterior insertion of the adipose fin; (6) dorsal insertion of the caudal fin; (7) median insertion of the caudal fin; (8) ventral insertion of the caudal fin; (9) insertion of the anal fin; (10) insertion of the pelvic fin; (11) insertion of the pectoral fin; in addition the following distances were calculated: the distances between the spots centroid and the fish centroid, the distances between the spots centroid and landmark 1, the average distance of brown spots from the intersection between landmark 1-landmark 7 and the perpendicular and the land mark 3 (black circle). dorsal fin with a wider base, and a higher proportion of brown spots. The higher number of red spots aligned to the fish lateral line appeared to be a distinctive character for the Atlantic specimens.

Regarding the differences between Mediterranean individuals broken down by sampling site, the discriminant analysis on Mediterranean group revealed significant differences among the three populations considered (Ambro, San Leonardo and Torsa populations) $(p<0.001)$. The Tenna and Nera populations were excluded from the analysis because of the low number of specimens. Two significant discriminant functions were provided (Wilks' lambda $=0.069, p<0.001$ ), with the first two accounting for $77.0 \%$ and $23.0 \%$, respectively (Fig. 5). The variables extracted from the stepwise analysis are shown in Table 4. Specimens located to the right side of DF1 belonged to the San Leonardo creek. The variables that contributed most to explain these positions were: the distances between landmarks located mainly in the caudal part of the fish $(6-7,9-10,5-8,7-8,6-9,8-9)$; the proportion of red spots, the number of red spots aligned along the lateral line, and the distance between landmark1-brown spots centroid. The ANOVA results allowed us to highlight that the San Leonardo creek population was characterized by a less high pectoral fin, a more elongated caudal peduncle indicated by the higher distances between landmarks $6-7$ and $7-8$, a larger number of red spots on the lateral line and by the grouping of the brown points at the back of the flanks (Tab. 5).

Along DF2, the Torsa population partially overlaps with that of Ambro river. The variables that distinguish the Torsa population were the more extended pectoral fins, the larger proportion of red spots and a smaller frequency of brown and black spots (Tab. 5).

\section{Discussion}

The present research is based on an approach that is different from the one used in the classical works of morphometry, in which the specimens are grouped according to different liveries (Zaccara et al., 2015). In fact, in this case the morphological analyses were carried out on genetically characterized specimens. This approach resulted in very detailed information about the correspondence between genotypic and phenotypic characteristics of the analyzed specimens. The results obtained confirmed the efficiency of morphological tools in detecting brown trout introduction in wild populations; they acquire a relevant meaning, also considering that relatively few studies have been carried out on the role of morphological characters in the discrimination of native and introduced brown trout in Italy.

Results of both the correspondence analysis and the linear discriminant analysis, performed using both qualitative and quantitative variables, revealed two distinct phenotypic groups and confirmed, at a morphological level, the genetic separation between Atlantic and Mediterranean trout. Our analysis indicates that a set of phenotypic traits could be useful for differentiating alien brown trout from native ones; moreover, these traits could help in a preliminary assessment of a trout population status, allowing the identification of alien specimens during field monitoring. More difficulties persist, however, in the identification of hybrids with respect to 
Table 2. Variables that showed statistically significant differences among genetic groups (Mediterranean, Introgressed/Hybrid, Atlantic) at the one-way ANOVA.

\begin{tabular}{|c|c|c|c|c|c|}
\hline \multirow[t]{2}{*}{ Variables } & \multicolumn{3}{|c|}{ Genetic group } & \multirow[t]{2}{*}{$F$} & \multirow[t]{2}{*}{$p$} \\
\hline & $\begin{array}{l}\text { Mediterranean } \\
(n=108) \\
\text { mean } \pm \mathrm{SD}\end{array}$ & $\begin{array}{l}\text { Hybrid } \\
(n=77) \\
\text { mean } \pm \text { SD }\end{array}$ & $\begin{array}{l}\text { Atlantic } \\
(n=73) \\
\text { mean } \pm \text { SD }\end{array}$ & & \\
\hline Height of anal fin & $2.58 \pm 0.31$ & $2.37 \pm 0.09$ & $2.35 \pm 0.16$ & 11.82 & 0.000 \\
\hline Distance between landmarks $1-2$ & $1.64 \pm 0.12$ & $1.53 \pm 0.04$ & $1.63 \pm 0.08$ & 13.38 & 0.000 \\
\hline Distance between landmarks $1-3$ & $7.52 \pm 0.20$ & $7.36 \pm 0.24$ & $7.56 \pm 0.19$ & 2.70 & 0.031 \\
\hline Distance between landmarks $1-10$ & $8.83 \pm 0.23$ & $8.85 \pm 0.08$ & $8.85 \pm 0.20$ & 2.81 & 0.026 \\
\hline Distance between landmarks $2-9$ & $10.69 \pm 0.24$ & $10.94 \pm 0.16$ & $10.97 \pm 0.19$ & 14.26 & 0.000 \\
\hline Distance between landmarks 3-4 & $2.36 \pm 0.17$ & $2.46 \pm 0.36$ & $2.32 \pm 0.14$ & 3.49 & 0.009 \\
\hline Distance between landmarks $3-5$ & $5.70 \pm 0.21$ & $5.90 \pm 0.13$ & $5.60 \pm 0.21$ & 4.62 & 0.001 \\
\hline Distance between landmarks 3-10 & $3.76 \pm 0.19$ & $3.79 \pm 0.25$ & $3.66 \pm 0.18$ & 3.46 & 0.009 \\
\hline Distance between landmarks 5-7 & $3.40 \pm 0.18$ & $3.37 \pm 0.03$ & $3.44 \pm 0.20$ & 8.07 & 0.000 \\
\hline Distance between landmarks 5-9 & $2.79 \pm 0.14$ & $2.64 \pm 0.11$ & $2.71 \pm 0.13$ & 4.76 & 0.001 \\
\hline Distance between landmarks 6-7 & $1.38 \pm 0.14$ & $1.26 \pm 0.02$ & $1.32 \pm 0.13$ & 3.55 & 0.008 \\
\hline Distance between landmarks $6-8$ & $1.74 \pm 0.09$ & $1.65 \pm 0.02$ & $1.74 \pm 0.11$ & 5.06 & 0.001 \\
\hline Distance between landmarks $7-8$ & $1.47 \pm 0.13$ & $1.57 \pm 0.17$ & $1.41 \pm 0.12$ & 3.42 & 0.010 \\
\hline Distance between landmarks $7-11$ & $12.45 \pm 0.31$ & $12.75 \pm 0.10$ & $12.57 \pm 0.31$ & 3.38 & 0.010 \\
\hline Distance between landmark 1-brown spots centroid & $11.69 \pm 4.92$ & $11.00 \pm 1.50$ & $10.53 \pm 3.36$ & 2.82 & 0.026 \\
\hline Distance between landmark 1-black spots centroid & $11.35 \pm 4.20$ & $10.72 \pm 0.64$ & $10.69 \pm 2.42$ & 5.09 & 0.001 \\
\hline Distance between landmark 1-red spots centroid & $13.40 \pm 3.26$ & $12.95 \pm 0.31$ & $12.85 \pm 0.83$ & 4.22 & 0.003 \\
\hline Frequency of red spots & $34.87 \pm 17.35$ & $11.50 \pm 7.78$ & $19.49 \pm 6.06$ & 12.85 & 0.000 \\
\hline Proportion of brown spots & $0.24 \pm 0.14$ & $0.33 \pm 0.32$ & $0.13 \pm 0.08$ & 11.34 & 0.000 \\
\hline Intensity of black spots & $1.31 \pm 1.16$ & $0.76 \pm 0.20$ & $1.03 \pm 0.79$ & 2.49 & 0.044 \\
\hline Intensity of red spots & $1.03 \pm 0.54$ & $0.26 \pm 0.11$ & $0.57 \pm 0.29$ & 10.61 & 0.000 \\
\hline Number of red spots aligned to the fish lateral line & $7.52 \pm 2.69$ & $7.00 \pm 4.24$ & $9.03 \pm 2.08$ & 7.10 & 0.000 \\
\hline Number of ocular spots & $2.69 \pm 0.78$ & $2.50 \pm 0.71$ & $2.18 \pm 0.74$ & 6.66 & 0.000 \\
\hline Number of opercular spots & $12.60 \pm 6.67$ & $8.00 \pm 1.41$ & $2.88 \pm 2.28$ & 39.01 & 0.000 \\
\hline Number of parr marks & $14.86 \pm 6.74$ & $2.50 \pm 2.12$ & $5.83 \pm 4.50$ & 22.30 & 0.001 \\
\hline
\end{tabular}

Table 3. Discriminant analysis between genetic groups (Mediterranean, Introgressed/Hybrid, Atlantic): summary statistics of the Stepwise Analysis.

\begin{tabular}{llll}
\hline Variable & $F$ & $\lambda$ & $p$ \\
\hline Number of opercular spots & 58.21 & 0.687 & 0.001 \\
Number of parr marks & 44.61 & 0.548 & 0.001 \\
Number of red spots on the lateral line & 35.76 & 0.493 & 0.001 \\
Proportion of brown spots & 31.38 & 0.446 & 0.001 \\
Intensity of red spots & 27.08 & 0.422 & 0.001 \\
Intensity of black spots & 24.55 & 0.396 & 0.001 \\
Distance between landmarks 1-2 & 22.14 & 0.380 & 0.006 \\
Distance between landmarks 3-4 & 23.59 & 0.322 & 0.001 \\
Height of anal fin & 22.33 & 0.304 & 0.001 \\
Distance between landmarks 7-8 & 20.92 & 0.292 & 0.007 \\
Number of ocular spots & 29.59 & 0.283 & 0.022 \\
\hline
\end{tabular}

parental forms, with which evident margins of overlap occurred, as already showed by Mezzera et al. (1997). The morphological variables that play a key role in the discrimination of the Mediterranean trout were: (i) striped pattern of parr marks, (ii) adipose fin mainly with white color
Table 4. Discriminant analysis among watercourses within Mediterranean group: summary statistics of the stepwise analysis.

\begin{tabular}{llll}
\hline Variable & $F$ & $\lambda$ & $p$ \\
\hline Proportion of red spots & 43.89 & 0.525 & 0.001 \\
Distance between landmarks 6-7 & 35.24 & 0.332 & 0.001 \\
Number of red spots aligned along & 32.50 & 0.244 & 0.001 \\
the lateral line & & & \\
Distance between landmarks 9-10 & 30.34 & 0.191 & 0.001 \\
Distance between landmarks 5-8 & 26.58 & 0.169 & 0.004 \\
Distance between landmarks 7-8 & 24.21 & 0.150 & 0.004 \\
Distance between landmarks 6-9 & 23.31 & 0.128 & 0.001 \\
Distance between landmarks 8-9 & 22.22 & 0.113 & 0.003 \\
Distance between landmark1-brown & 20.74 & 0.104 & 0.028 \\
spots centroid & & & \\
\hline
\end{tabular}

and without black spots, and (iii) reduced red dots alignment to the fish lateral line, compared to the Atlantic trout, as already shown for Western Europe (Mezzera et al., 1997; Aparicio et al., 2005). According to Aparicio et al. (2005), hatcheryreared Atlantic trout frequently lack the preopercular dot. Our 


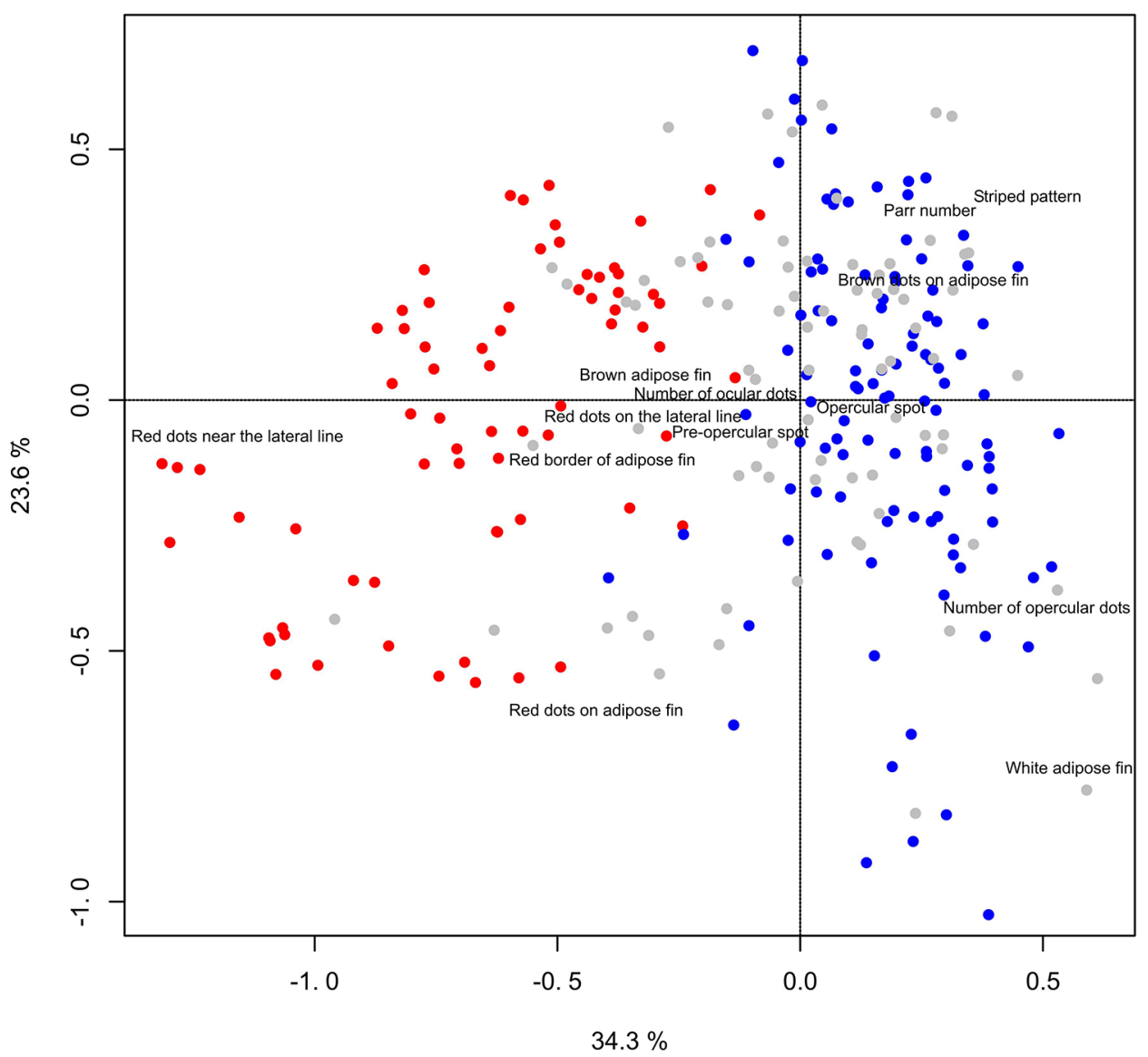

Fig. 3. Correspondence analysis results. Red, blue and grey spots represented Atlantic, Mediterranean and Introgressed/Hybrid specimens, respectively.

results suggested that the color pattern of native brown trout in Central Italy is very similar to those of other Mediterranean populations: native brown trout of Mediterranean rivers from Spain and France were characterized by a fine spotting pattern with a high number of red and black spots on their body flanks (Poteaux and Berrebi, 1997; Aparicio et al., 2005), with persistent parr marks in the adult stage (Largiadèr and Scholl, 1996; Mezzera et al., 1997). On the basis of morphological evaluations (Ielli and Alessio, 1996), subsequently confirmed by the genetic analysis (Zaccara et al., 2015), also the spotted pattern of the native populations of Italian peninsula has been identified as showing a clearly defined, black preopercular dot and a fine spotting pattern on body sides. The color pattern of the Atlantic trout is instead characterized by the presence of a few circular black spots, red spots aligned mainly along the lateral line, parr marks less persistent during growth and without striped pattern, few opercular spots, and often the absence of the pre-opercular dot.

The Mediterranean trout populations occurring in the central Apennines seem to differ significantly, from the morphological point of view, from those present in southeastern Sicily (Vinciguerra, 1896; Sommani, 1950a), as recently described by Duchi (2018), which are also genetically distinct from other Italian populations (Schöffmann et al., 2007; Fruciano et al., 2014) and more similar to populations from North Africa (Tougard et al., 2018). The binome $S$. cettii was previously used to identify the Sicilian populations, and this poses problems of nomenclature concerning the other Italian populations.

As regards the geometric analysis, the results showed a set of particularly significant parameters in discriminating genetic groups, as they are less affected by environmental conditions; in particular the analysis of the distances between landmarks revealed that hybrid specimens were characterized by a dorsal fin with a wider base and a less elongated snout compared to the Mediterranean and Atlantic individuals.

The discriminant analysis results performed within Mediterranean group revealed that some morphologic parameters, as the proportion of red spots, the number of red spots on the lateral line, the shape of the caudal peduncle, and the spatial arrangement of brown spots on the fish flank, are useful for separating the populations of the watercourses belonging to the same catchment basin, even if the analysis did not reveal the occurrence of greater similarities between populations inhabiting watercourses that are closely related from a geographical point of view. It is interesting the fact that the San Leonardo creek trout population considerably differs from that of Ambro river; this seems to be due to the long history of isolation of the San Leonardo creek population, which also emerged from the results of genetic analysis (Splendiani et al., 2019), that is isolated from the rest of the basin by the presence of a natural barrier insurmountable from the fish fauna.

In any case, while the morphological differences that allow to distinguish the alien Atlantic trout from the native 


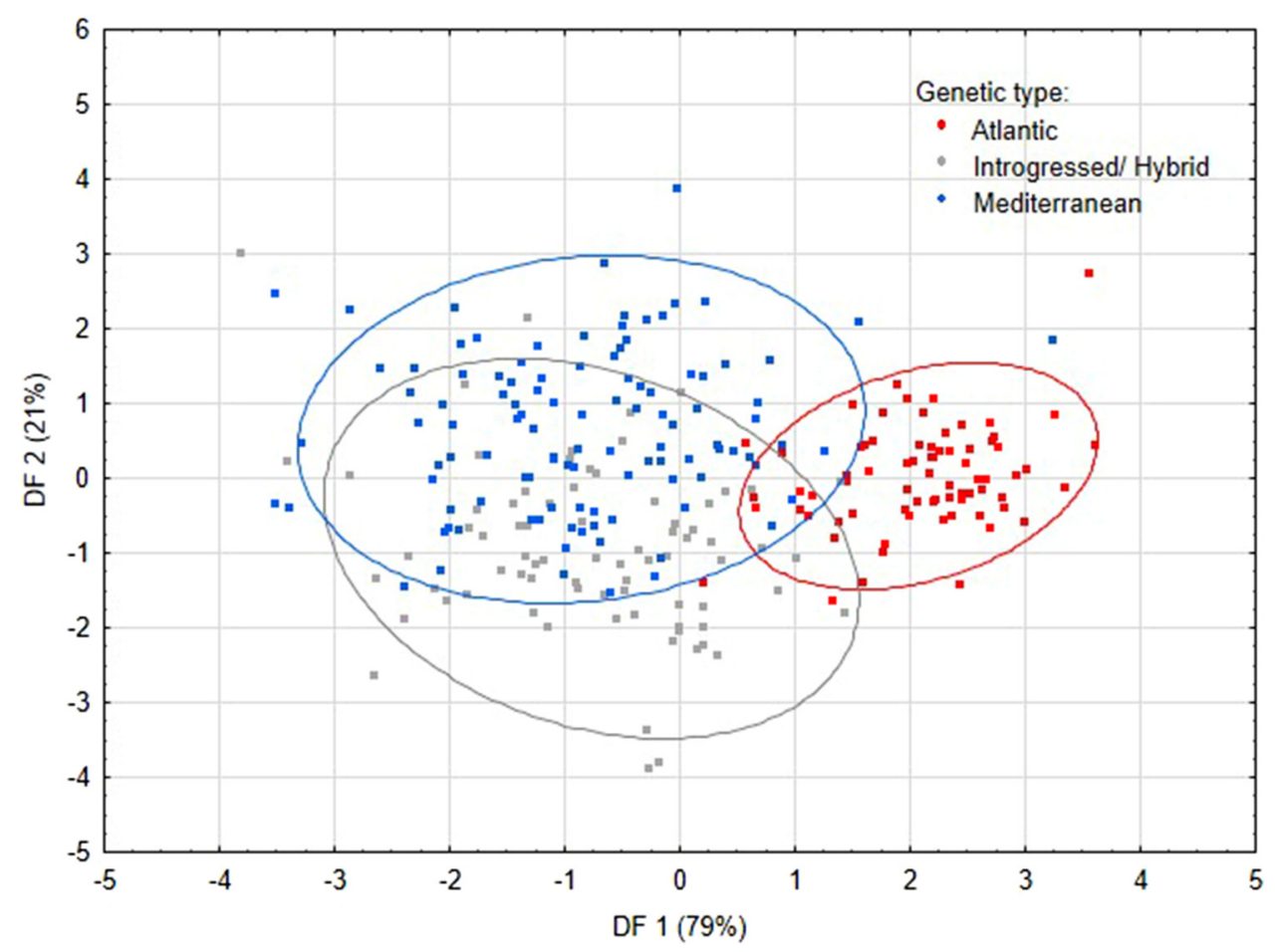

Fig. 4. Discriminant analysis between groups. Dots represent individuals. Groups (numbers and ellipses) are positioned on the plane using their values for two variables. The genetic types were identified on the basis of the $q$ values: $q \geq 0.998=$ Mediterranean; $0.005<q<$ $0.998=$ Introgressed/hybrid; $q \leq 0.005=$ Atlantic).

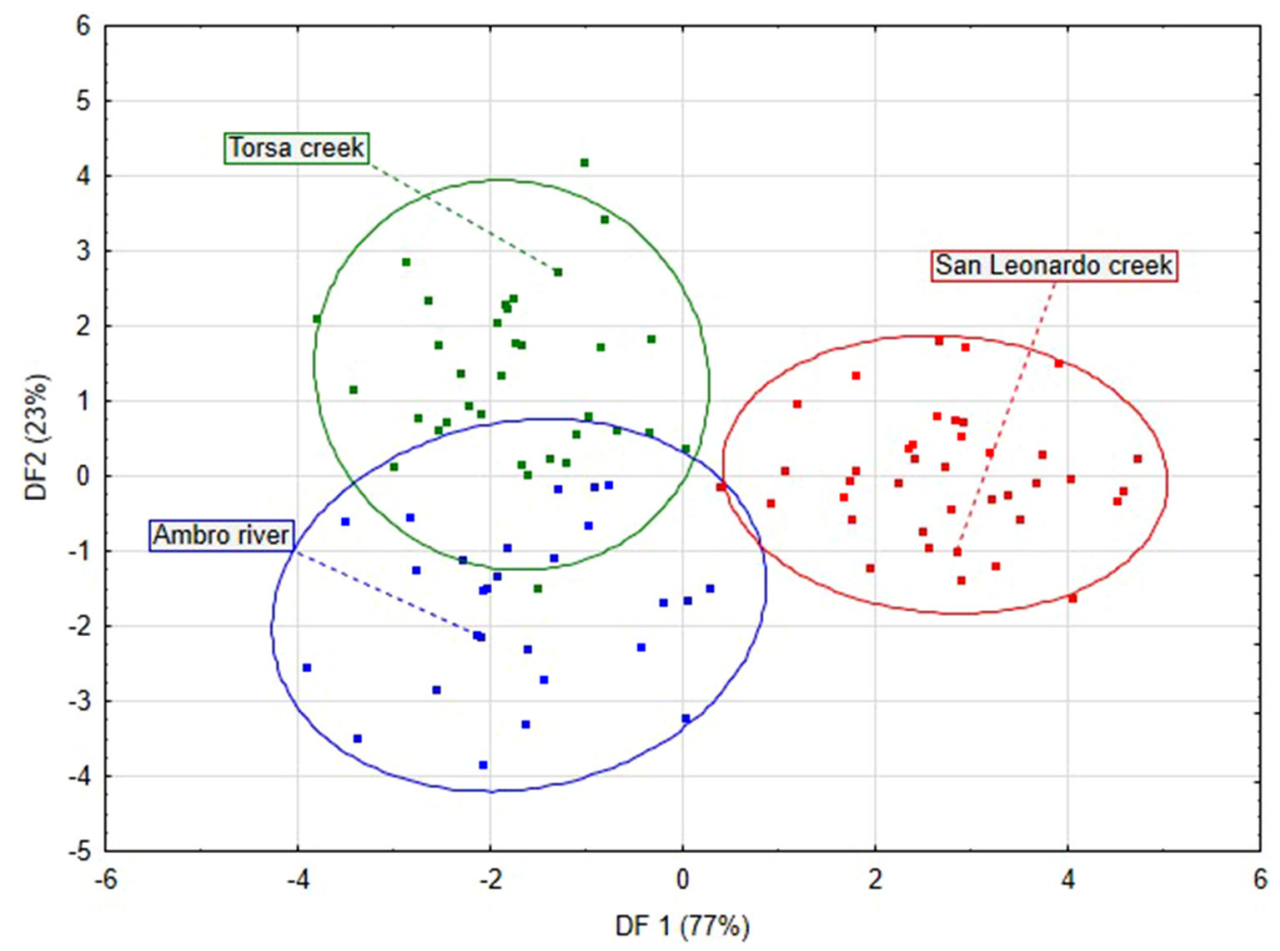

Fig. 5. Discriminant analysis within Mediterranean group. Ellipses identify the three Mediterranean populations detected in the study area. Sampling site. 
Table 5. Variables that showed statistically significant differences among watercourses within Mediterranean genetic group at the one-way ANOVA.

\begin{tabular}{|c|c|c|c|c|c|}
\hline \multirow[t]{2}{*}{ Variables } & \multicolumn{3}{|c|}{ Genetic group } & \multirow[t]{2}{*}{$F$} & \multirow[t]{2}{*}{$p$} \\
\hline & $\begin{array}{l}\text { Ambro mean } \pm \text { SD } \\
(n=27)\end{array}$ & $\begin{array}{l}\text { San Leonardo } \\
\text { mean } \pm \text { SD } \\
(n=39)\end{array}$ & $\begin{array}{l}\text { Torsa mean } \pm \text { SD } \\
(n=34)\end{array}$ & & \\
\hline Height of pectoral fin & $2.83 \pm 0.27$ & $1.92 \pm 1.21$ & $2.97 \pm 0.56$ & 16.86 & 0.001 \\
\hline Height of anal fin & $2.61 \pm 0.17$ & $2.45 \pm 0.43$ & $2.69 \pm 0.16$ & 5.83 & 0.004 \\
\hline Height of dorsal fin & $2.30 \pm 0.19$ & $2.44 \pm 0.22$ & $2.35 \pm 0.16$ & 4.26 & 0.016 \\
\hline Distance between landmarks $1-2$ & $1.56 \pm 0.11$ & $1.66 \pm 0.10$ & $1.68 \pm 0.10$ & 10.17 & 0.001 \\
\hline Distance between landmarks $4-5$ & $3.37 \pm 0.28$ & $3.24 \pm 0.19$ & $3.43 \pm 0.26$ & 5.93 & 0.003 \\
\hline Distance between landmarks $5-8$ & $2.73 \pm 0.14$ & $2.98 \pm 0.21$ & $2.79 \pm 0.20$ & 9.37 & 0.001 \\
\hline Distance between landmarks 5-10 & $5.15 \pm 0.24$ & $4.85 \pm 0.25$ & $5.02 \pm 0.15$ & 15.99 & 0.001 \\
\hline Distance between landmarks 6-7 & $1.29 \pm 0.11$ & $1.49 \pm 0.12$ & $1.36 \pm 0.10$ & 31.97 & 0.001 \\
\hline Distance between landmarks 6-9 & $4.01 \pm 0.15$ & $3.84 \pm 0.17$ & $3.97 \pm 0.14$ & 11.40 & 0.001 \\
\hline Distance between landmarks $7-8$ & $1.44 \pm 0.13$ & $1.52 \pm 0.14$ & $1.44 \pm 0.10$ & 5.56 & 0.005 \\
\hline Distance between landmarks 8-9 & $3.08 \pm 0.18$ & $3.18 \pm 0.22$ & $3.15 \pm 0.20$ & 3.14 & 0.048 \\
\hline Distance between landmarks 9-10 & $3.22 \pm 0.20$ & $2.95 \pm 0.21$ & $3.03 \pm 0.18$ & 15.77 & 0.001 \\
\hline Distance between landmarks $10-11$ & $4.95 \pm 0.18$ & $5.09 \pm 0.26$ & $5.09 \pm 0.24$ & 3.13 & 0.048 \\
\hline Distance between landmark 1-brown spots centroid & $10.96 \pm 2.48$ & $14.54 \pm 5.33$ & $9.70 \pm 4.27$ & 12.13 & 0.001 \\
\hline Distance between landmark 1-black spots centroid & $9.91 \pm 3.05$ & $14.10 \pm 4.76$ & $9.53 \pm 3.05$ & 15.84 & 0.001 \\
\hline Distance between landmark 1-red spots centroid & $12.48 \pm 0.79$ & $15.22 \pm 4.88$ & $12.29 \pm 0.60$ & 10.03 & 0.001 \\
\hline Frequency of brown spots & $33.10 \pm 28.44$ & $36.05 \pm 19.80$ & $12.44 \pm 11.82$ & 13.64 & 0.001 \\
\hline Frequency of black spots & $42.61 \pm 37.36$ & $69.10 \pm 32.52$ & $18.43 \pm 12.84$ & 27.70 & 0.001 \\
\hline Frequency of red spots & $27.45 \pm 14.09$ & $39.59 \pm 15.44$ & $36.36 \pm 15.25$ & 5.36 & 0.006 \\
\hline Proportion of brown spots & $0.31 \pm 0.15$ & $0.25 \pm 0.10$ & $0.16 \pm 0.11$ & 12.40 & 0.001 \\
\hline Proportion of black spots & $0.36 \pm 0.21$ & $0.47 \pm 0.12$ & $0.26 \pm 0.13$ & 15.44 & 0.001 \\
\hline Proportion of red spots & $0.33 \pm 0.18$ & $0.28 \pm 0.09$ & $0.57 \pm 0.14$ & 43.89 & 0.001 \\
\hline Intensity of brown spots & $0.92 \pm 0.86$ & $0.97 \pm 0.53$ & $0.32 \pm 0.30$ & 13.11 & 0.001 \\
\hline Intensity of black spots & $1.12 \pm 0.96$ & $1.82 \pm 0.89$ & $0.48 \pm 0.34$ & 27.27 & 0.001 \\
\hline Intensity of red spots & $0.74 \pm 0.37$ & $1.06 \pm 0.40$ & $0.95 \pm 0.39$ & 5.36 & 0.006 \\
\hline Number of red spots aligned to the fish lateral line & $6.69 \pm 2.02$ & $9.32 \pm 2.49$ & $6.12 \pm 2.52$ & 18.57 & 0.001 \\
\hline Number of opercular spots & $14.03 \pm 6.38$ & $13.76 \pm 4.98$ & $10.93 \pm 5.65$ & 3.09 & 0.050 \\
\hline
\end{tabular}

Mediterranean trout resulted very clear, it is necessary to deepen the research to clarify the differential characteristics existing among the different Mediterranean trout populations. As suggested by some authors (Sommani, 1950b), the level of differentiation of the Mediterranean trout is complicated by the interaction of historical, geographical and ecological factors. Moreover, in the different populations a high degree of phenotypic variability occur, and it can be partly justified by the environmental differences existing between watercourses (Zaccara et al., 2015; Ferguson et al., 2016) and partly by the geographic isolation level of the local populations (Pomini, 1941; Sommani, 1950a). It is known that salmonids develop liveries with particular color patterns in response to some environmental parameters, such as water transparency and bottom structure (Bourke et al., 1997; Ferguson et al., 2016); backs and flanks with a thick maculation (red, black and parr spots) allow trout to blend in with the gravel of the bottom and with the reflections of light created in the shallow water by the ripples of the surface. On the other hand, silvery flanks with only a few black spots help to camouflage the fish in deeper waters. Indeed, the trout inhabiting the pelagic environments do not stand out against the bottom, regardless of the direction from which they are seen by predators (Crozier and Ferguson,
1986; Olsson and Greenberg, 2004). In the native trout of the Apennine, the presence of a relationship between the maculation on the sides with the longitudinal gradient has already been highlighted in the past (Lorenzoni et al., 2003), with the abundance of red dots decreasing in the river areas located further downstream and characterized by higher flow rates (Sommani, 1950b). From the analysis carried out on wild fish moved to the farm, the same changes resulted in association with age (Lorenzoni, unpublished data). It is known that in natural conditions trout change their habitat preferences during growth; shallow and rippled waters are favored by young specimens, which move in deeper and more downstream reaches with aging. However, Duchi (2018) in the autochthonous trout populations of Sicily did not find any relationship between spotted pattern characteristics (maculation) and age. In trout some shape changes, probably associated with greater swimming efficiency, are also known; the snout more pointed, the leaner and slimmer body, and the elongation of the caudal peduncle (Hard et al., 1999) characterize individuals inhabiting more reophilic environments. Other morphological characters, such as the size of fins, have been associated with sexual dimorphism (Lorenzoni et al., 2003). 
The main practical application of the present research consists in the management and protection of native trout populations by providing greater attention to the identification of protected areas for the biodiversity conservation, also in view of the fact that current knowledge on the morphology of the endemic salmonids in Italy is limited. The application of morphological analysis methods is advantageous since it is not cruel, it is inexpensive and easy to apply in the field. In case of moderately introgressed populations subject to fishing pressure, it may be possible in the long-term to significantly reduce the rate of introgression if individuals classified as nonnative and hybrids through their selective removal from the population (Aparicio et al., 2005). However, further researches are needed to develop a model based on the most discriminating phenotypic characteristics in order to predict the genetic status of brown trout populations in the study area.

The results obtained during the research provided, ultimately, useful tools for the advancement of knowledge and management of the native fish fauna, with positive effects on the conservation of a species complex at high risk of extinction, due to the synergistic combination of the direct impact of human activities on inland waters and global climate change.

Acknowledgements. This study was funded by Life+ TROUT Project (LIFE12 NAT/IT/0000940) for the recovery and conservation of Mediterranean trout (Salmo trutta complex) in the central Apennines (Italy), within the framework of the European Commission Life Projects. The authors wish to thank all of the people who joined in the field activities during the project.

\section{References}

Abramoff MD, Magalhães PJ, Ram SJ. 2004. Processing with Image J. Biophotonics Int 11: 36-42.

Adams DC, Rohlf FJ, Slicec DE. 2013. A field comes of age: geometric morphometrics in the 21st century. Hystrix 24: 7-14.

Almodovar A, Nicola G, Ayllon D, Elvira B. 2011. Global warming threatens the persistence of Mediterranean brown trout. Glob Change Biol 18: 1549-1560.

Aparicio E, García-Berthou E, Araguas RM, Martínez P, GarcíaMarin JL. 2005. Body pigmentation pattern to assess introgression by hatchery stocks in native Salmo trutta from Mediterranean streams. J Fish Biol 67: 931-949.

Araguas RM, Vera M, Aparicio E, et al. 2017. Current status of the brown trout (Salmo trutta) populations within eastern Pyrenees genetic refuges. Ecol Freshw Fish 26: 120-132.

Bagenal TB. 1978. Fish production in fresh waters. Oxford: Blackwell, $250 \mathrm{p}$.

Berrebi P, Poteaux C, Fissier M, Cattaneo-Berrebi G. 2000. Stocking impact and allozyme diversity in brown trout from Mediterranean southern France. J Fish Biol 56: 949-960.

Bourke P, Magnan P, Rodriguez MA. 1997. Individual variations in habitat use and morphology in brook char. J Fish Biol 51: 783-794.

Buisson L, Thuiller W, Sovan L, Lim P, Grenouillet G. 2008. Climate change hastens the turnover of stream fish assemblages. Glob Change Biol 14: 2232-2248.

Cadrin SX. 2000. Advances in morphometric identification of fishery stocks. Rev Fish Biol Fisheries 10: 91-112.
Caputo V, Giovanotti M, Nisi Cerioni P, Caniglia ML, Splendiani A. 2004. Genetic diversity of brown trout (Salmo trutta L., 1758) in central Italy. J Fish Biol 65: 403-418.

Carosi A, Ghetti L, Forconi A, Lorenzoni M. 2015. Fish community of the river Tiber basin (Umbria-Italy): temporal changes and possible threats to native biodiversity. Knowl Manag Aquat Ecosyst 416: 22.

Clavero M, Hermoso V, Kark S, Levin N. 2010. Geographical linkages between threats and imperilment in freshwater fish in the Mediterranean Basin. Divers Distrib 16: 744-754.

Crozier WW, Ferguson A. 1986. Electrophoretic examination of the population structure of brown trout, Salmo trutta L., from the Lough Neagh catchment, Northern Ireland. J Fish Biol 208: 459477.

Duchi A. 2018. Flank spot number and its significance for systematics, taxonomy and conservation of the near-threatened Mediterranean trout Salmo cettii: evidence from a genetically pure population. J Fish Biol 92: 254-260.

Dudgeon D, Arthington AH, Gessner MO, et al. 2006. Freshwater biodiversity: Importance, threats, status and conservation challenges. Biol Rev 81: 163-182.

Falush D, Stephens M, Pritchard JK. 2003. Inference of population structure using multilocus genotype data: linked loci and correlated allele frequencies. Genetics 164: 1567-1587.

Ferguson A, Reed T, Mcginnity P, Prodöhl P. 2016. Anadromy in brown trout (Salmo trutta): a review of the relative roles of genes and environmental factors and the implications for management and conservation, in Proceedings of the 2nd International Sea Trout Symposium, Dundalk, Ireland.

Ficke AD, Myrick CA, Hansen LJ. 2007. Potential impacts of global climate change on freshwater fisheries. Rev Fish Biol Fisheries 17: 581-613.

Filipe F, Markovic D, Pletterbauer F. 2013. Forecasting fish distribution along stream networks: brown trout (Salmo trutta) in Europe. Divers Distrib 19: 1059-1071.

Fruciano C, Pappalardo AM, Tigano C, Ferrito V. 2014. Phylogeographical relationships of Sicilian brown trout and the effects of genetic introgression on morphospace occupation. Biol J Linnean Soc 112: 387-398.

Genovesi P, Angelini P, Bianchi E, et al. 2014. Specie e habitat di interesse comunitario in Italia: distribuzione, stato di conservazione e trend. ISPRA, Serie Rapporti, 194/2014.

Giuffra E, Guyomard R, Forneris G. 1996. Phylogenetic relationships and introgression patterns between incipient parapatric species of Italian brown trout (Salmo trutta L. complex). Mol Ecol 5: 207220.

Gratton P, Allegrucci G, Gandolfi AV, Sbordoni V. 2013. Genetic differentiation and hybridization in two naturally occurring sympatric trout Salmo spp. forms from a small karstic lake. $J$ Fish Biol 82: 637-657.

Gratton P, Allegrucci G, Sbordoni V, Gandolfi A. 2014. The evolutionary jigsaw puzzle of the surviving trout (Salmo trutta L. complex) diversity in the Italian region. A multilocus Bayesian approach. Mol Phylogen Evol 79: 292-304.

Hansen MM. 2002. Estimating the long-term effects of stocking domesticated trout into wild brown trout (Salmo trutta) populations: an approach using microsatellite DNA analysis of historical and contemporary samples. Mol Ecol 11: $1003-1015$.

Hard JJ, Winans GA, Richardson JC. 1999. Phenotypic and genetic architecture of juvenile morphometry in Chinook salmon. $J$ Heredity 90: 597-606. 
Hayden B, Pulcini D, Kelly-Quinn M, et al. 2010. Hybridisation between two cyprinid fishes in a novel habitat: genetics, morphology and life-history traits. BMC Evolut Biol 10: 169.

Ielli F, Alessio G. 1996. Recovery and conservation of small brown trout Salmo trutta L. population in the northern central Apennine (Reggio Emilia, Italy), Proceedings IV National Congress Italian Freshwater Ichthyologist Association, pp. 459-466.

Kottelat M, Freyhof J. 2007. Handbook of European Freshwater Fishes. Cornol: Kottelat, 646 p.

Largiadèr CR, Scholl A. 1996. Genetic introgression between native and introduced brown trout Salmo trutta L. populations in the Rhone River Basin. Mol Ecol 5: 417-426.

Lleonart J, Salat J, Torres GJ. 2000. Removing allometric effects of body size in morphological analysis. $J$ Theor Biol 205: 85-93.

Lorenzoni M, Carosi A, Panara F. 2003. Il recupero del ceppo autoctono della trota fario nel bacino idrografico del Fiume Nera, Arti Grafiche Nobili, Terni, 182 p.

Lorenzoni M, Maio G, Nonnis Marzano F. 2004. Stato attuale delle conoscenze sulle popolazioni autoctone di trota in Italia: necessità di un approccio integrato. Quaderni ETP 33: 1-12.

Lorenzoni M, Carosi A, Giovannotti M, La Porta G, Splendiani A, Caputo Barucchi V. 2018. Population status of the native Cottus gobio after removal of the alien Salmo trutta: a case-study in two Mediterranean streams (Italy). Knowl Manag Aquat Ecosyst 419: 22.

Lorenzoni M, Carosi A, Giovannotti M, La Porta G, Splendiani A, Caputo Barucchi V. 2019. Ecology and conservation of the Mediterranean trout in the central Apennines (Italy). J Limnol 78: $1-13$.

Mezzera M, Largiadèr CR, Scholl A. 1997. Discrimination of native and introduced brown trout in the River Doubs (Rhône drainage) by number and shape of parr marks. J Fish Biol 50: 672-677.

Myers N, Mittermeier RA, Mittermeier CG, da Fonseca GAB, Kent J. 2000. Nature 403: 853-858.

Nonnis Marzano F, Corradi N, Papa R, Tagliavini J, Gandolfi G. 2003. Molecular evidence for introgression and loss of genetic variability in Salmo (trutta) macrostigma as a result of massive restocking of Appenine populations (Northern and Central Italy). Environ Biol Fishes 68: 349-356.

Olsson IC, Greenberg LA. 2004. Partial migration in a landlocked brown trout population. J Fish Biol 65: 106-121.

Pedicillo G, Carosi A, Ghetti L, Lorenzoni M. 2010. Population size structure indices and growth standards for Salmo (trutta) trutta Linnaeus, 1758 in Central Italy. Knowl Manag Aquat Ecosyst 399: $1-15$.

Pomini FP. 1941. Ricerche sui Salmo dell'Italia peninsulare I. La trota del Sagittario, Salmo ghigii (n.sp.) Atti Soc Ital Sc Nat 80: $33-48$.

Poteaux C, Berrebi P. 1997. Genome integrity and trout restocking on the Mediterranean versant. Bull Fr Peche Pisc 344/345: 309-322.

Poteaux CF, Bonhomme F, Berrebi P. 1999. Microsatellite polymorphism and genetic impact of restocking in Mediterranean brown trout (Salmo trutta L.). Heredity 82: 645-653.
Pritchard JK, Stephens M, Donnelly P. 2000. Inference of population structure using multilocus genotype data. Genetics 155: 945-959.

Querci G, Pecchioli E, Leonzio C, Frati F, Nardi F. 2013. Molecular characterization and hybridization in Salmo (trutta) macrostigma morphotypes from Central Italy. Hydrobiologia 702: 191-200.

R Core Team. 2016. R: A language and environment for statistical computing. Vienna, Austria: R Foundation for Statistical Computing. Available at: https://www.R-project.org/

Rhymer JM, Simberloff D. 1996. Extinction by hybridization and introgression. Annu Rev Ecol Syst 27: 83-109.

Rondinini C, Battistoni A, Peronace V, Teofili C. 2013. Lista Rossa IUCN dei Vertebrati Italiani, Comitato Italiano IUCN e Ministero dell'Ambiente e della Tutela del territorio e del mare, Roma, $54 \mathrm{p}$.

Schöffmann J, Susnik S, Snoj A. 2007. Phylogenetic origin of Salmo trutta L 1758 from Sicily, based on mitochondrial and nuclear DNA analyses. Hydrobiologia 575: 51-55.

Smith KG, Darwall WRT. 2006. The status and distribution of freshwater fish endemic to the Mediterranean basin. IUCN, Gland, Switzerland and Cambridge, UK, $34 \mathrm{p}$.

Sommani E. 1950a. Osservazioni sulla sistematica ed ecologia delle trote dell'Italia meridionale. Bollettino di Pesca, Idrobiologia e Pescicoltura 5: 1-20.

Sommani E. 1950b. Notizie preliminari sulla sistematica ed ecologia delle trote in Italia. Ital J Zool 17: 535-542.

Splendiani A, Giovannotti M, Cerioni PN, Caniglia ML, Caputo V. 2006. Phylogeographic inferences on the native brown trout mtDNA variation in central Italy. Ital J Zool 73: 179-189.

Splendiani A, Ruggeri P, Giovannotti M, Caputo Barucchi V. 2013. Role of environmental factors in the spread of domestic trout in Mediterranean streams. Freshw Biol 58: 2089-2101.

Splendiani A, Ruggeri P, Giovannotti M, et al. 2016. Alien brown trout invasion of the Italian peninsula: the role of geological, climate and anthropogenic factors. Biol Invas 18: 2029-2044.

Splendiani A, Giovannotti M, Righi T, et al. 2019. Introgression despite protection: the case of native brown trout in Natura 2000 network in Italy. Conserv Genet 20: 343-356.

Strauss RE, Bookstein FL. 1982. The truss: body form reconstructions in morphometrics. Syst Zool 3: 113-135.

Suarez J, Bautista JM, Almodovar A, Machordom A. 2001. Evolution of the mitochondrial control region in Palaearctic brown trout (Salmo trutta) populations: the biogeographical role of the Iberian Peninsula. Heredity 87: 198-206.

Tougard C, Justy F, Guinand B, Douzery EJP, Berrebi P. 2018. Salmo macrostigma (Teleostei, Salmonidae): nothing more than a brown trout (S. trutta) lineage? J Fish Biol 93: 302-310.

Vinciguerra D. 1896. Relazione intorno alla pesca d'acqua dolce e di mare in Sicilia e ai modi di aumentarne il prodotto. Bollettino di Notizie Agrarie 29: 105-128.

Zaccara S, Trasforini S, Antognazza CM, Puzzi C, Britton JR, Crosa G. 2015. Morphological and genetic characterization of Sardinian trout Salmo cettii Rafinesque, 1810 and their conservation implications. Hydrobiologia 760: 205-223. 